\title{
NIHILISM, SELF-TRANSCENDENCE AND ABJECTION IN J.G. BALLARD'S CRASH
}

\author{
Carlos Sánchez Fernández, Universidad Nacional de Educación a \\ Distancia (UNED) \\ E-mail: csanchez319@alumno.uned.es
}

\begin{abstract}
This essay focuses on the explanation of some of the aspects of plot and characterisation in J.G. Ballard's novel Crash (1973) by drawing analogies with its postmodern cultural background. The fundamental idea is the characters' wish to transcend both the reductive nihilism of a society whose value system is dominated by performativity, and the limitations of the human condition, starting with the self and the body. Their journey will be fraught with the danger of complete nihilism as it implies giving in to the death drive. In the end, this submission will strand them in abjection and abhumanity.
\end{abstract}

Keywords: Crash, self-transcendence, postmodernity, performativity, nihilism, death drive, abjection, the car, violence, sex.

Resumen: Este artículo se centra en la explicación de determinados aspectos del argumento y la caracterización en Crash (1973), de J.G. Ballard, atendiendo a analogías derivadas de su contexto cultural postmoderno. La idea fundamental es el deseo de los personajes de transcender tanto el nihilismo reduccionista propio de una sociedad dominada por la performatividad, como las limitaciones propias de la condición humana, comenzando con la subjetividad y el cuerpo. Su trayectoria se verá amenazada por un nihilismo completo que conlleva el entregarse al instinto de muerte. Al final, esta sumisión les llevará a la abyección y a la des-humanización (ab-humanity).

Palabras clave: $\mathrm{Crash}$, auto-trascendencia, postmodernidad, performatividad, nihilismo, instinto de muerte, abyección, automóvil, violencia, sexo.

\section{INTRODUCTION: PLOT}

First of all, this essay provides a brief summary of J.G. Ballard's Crash, first published in 1973. Ballard, the novel's narrator, on the death of one Vaughan, whom he has been following ever since a car accident he had, reflects on how his life has completely changed. ${ }^{1}$ This happens during his recovery in hospital, where he undergoes a sort of protracted epiphany whereby everything around him acquires unexpected sexual, mostly perverse connotations, thus becoming aware of "the sexual possibilities of everything" (Ballard 2008: 19). To

1 To prevent any ambiguities, from now on we will always call Ballard the author 'J.G. Ballard', whereas we will refer to the narrator-character as 'Ballard'. 
begin with, he discovers the unexpected excitement one can get out of a stranger's death, that of the man behind the wheel of the car he collided with. Despite mutual promiscuous infidelity in his very open marriage with Catherine, the accident also projects his marital life into a new, more and more perverse dimension.

He starts a sexual, car-mediated affair with his victim's widow, Dr. Helen Remington. Together, they attend a car show where a celebrity accident is re-enacted by one Seagrave, a stunt actor Ballard is acquainted with, and Vaughan, a computer expert and a former TV scientist, as well as the novel's true protagonist. He is described by Ballard as a charismatic, narcissistic, sexually obsessed, aggressive, fanatical hoodlum and a "pushy careerist with a PhD"; in other words, a "madman" (Ballard 2008: 11, 48). After the show, as Helen already knows Vaughan, they all drive to Seagrave's home, where Ballard is introduced to a group of people obsessed with car crashes, all of them having undergone physical harm because of at least one. They all suffer from a sexual perversion called symphorophilia: the obsession with catastrophes such as car crashes, fires, etc., which leads them to stage, re-enact or witness them out of the sexual arousal they experience on their account ${ }^{2}$. The house is covered with hundreds of car crash photographs. Ballard is fascinated. Later on, Ballard, Remington and Vaughan go to a road research laboratory in order to watch some experimental car crash reels.

The sexual tension between Vaughan and Ballard grows. They both start roaming the areas near Heathrow airport on the lookout for car crashes. Catherine, in spite of her very likely death as a result, gets involved into these activities. She ends up having sex with Vaughan in front of Ballard, always in a car. Ballard does the same with Gabrielle; throughout their liaison, he penetrates her many scars as if they were as many technology-mediated sexual orifices. Aware that Vaughan is planning his own death in a final crash where Elizabeth Taylor is also meant to die, Ballard starts fantasising about his wife's death in an accident.

Sharing an acid-high ride, Ballard finally sodomises Vaughan. With her full, if tacit consent, Ballard exposes Catherine as a target for Vaughan. A few days later, the Ballards hear of Vaughan's death in a frustrated car attack on Elizabeth Taylor. Ballard is aware of his destiny and starts organising the details of his own death in a car crash.

\section{PERFORMATIVITY AND "HAPPY" NIHILISM}

Crash's cultural background corresponds to a post-industrial society where the only link between people is the economic imperative, understood as the duty to performativity and consumerism in a market where moral values are absent. This performativity, namely the optimisation of the global relationship between input and output in any system, has caused action, as long as it is performative and regardless of any other considerations, not to need to be meaningful any more: ends are not taken into account; consequently, all values, apart from performativity and profit, are henceforth irrelevant.

This has contributed to the advent of postmodernity, as modern axiological categories such as aim, unity or truth have all but disappeared from the socio-political horizon, and

2 "Symphorophilia" n.d.: n.p. "Symphorophilia". in PsychologyDictionary.org. September 1, 2019. https:// psychologydictionary.org/symphorophilia/. 
traditional values and institutions have entered a process of inexorable decline. In this way, Jean-François Lyotard describes the postmodern as "incredulity toward metanarratives" (1984: xxiv). ${ }^{3}$ Its consequence has been a fragmentation of the self, as a discourse that may integrate the different spheres of life into a coherent whole is no longer available to the individual in postmodernity. From now on, living among "provisional, contingent, temporary, and relative" narratives born "through the interaction of a group or groups for a specific reason and at a particular moment in time", truth will always be in a state of flux. In this way, only a "conditional" and "relative" meaning could be given to human activities, free from "the oppressive force of the authoritarianism" proper to the grand narrative (du Toit 2011: 87-88; Wicks 2003: 253).

Although Lyotard sees these developments as liberating, he concedes that the predominance of performativity in the social landscape makes for a reductive kind of nihilism in which any initiative on the part of the social agents can only be acceptable as a contribution to the system's efficient functioning. This "neo-nihilism" would then be directly linked to capitalism, resulting in the culmination of what he calls the "theology of atheism", a counterworking force against what he construes as the libidinal intensities delivered by the demise of the values, procedures and institutions of the Enlightenment in postmodern society (Woodward 2009: 127-28, 130-33).

Lyotard's diagnosis of our time comes very close to Julia Kristeva's in a number of respects. According to her, the acceleration of time and space in our Western societies is transforming people into "amphibian", "borderline" beings, bodies that act, reduced to buying and selling semiotically equivalent, "dull, shallow" goods and services. As the body is conquering little by little the "territory of the soul", while at the same time people are getting anaesthetised by the spectacle "in the form of the mass media", no longer possessing an "inner garden" to help them give a meaning to their lives, performativity is dooming many to a "withering" of their "psychic space" (McAfee 2004: 109-10).

Another champion of liberating postmodernity and even a paladin of nihilism, Gianni Vattimo, also alludes to the globalised "colonization" of the social and the political by the diktats of "supermarket culture" and the demands of "development at any cost" (Woodward 2009: 218, 216). In J.G. Ballard's own terms, this would lead to the most dreadful evil he can think of: life in England's (or the West's) suburbs, the "suburbanisation of the soul", life "trapped in the afternoon shopping malls of a limitless mediocrity", the "commodification of everything", the "universal acceptance of the shopping mall" (Gasiorek 2005: 192; Zinik 2014: 357). J.G. Ballard coincides in this with Heidegger, for whom one of the symptoms of nihilism is "the pre-eminence of the mediocre" (Heidegger 2000: 47). In this way, by substituting a lame utilitarianism for the by now dead or moribund morality of Christianity, and not being able to recognise any greatness any longer, most Western suburbanites would be "content to be slaves even when there are no masters" (Tanner 2000: 87). Thus, the sole purpose noticeable in people's lives seems to be the "gratification of instant and constantly renewable desire", most notably sexual desire (Silverman 1999: 88).

3 Metanarratives can be defined as the linguistic-ideological constructs that have shaped our worldview in an all-encompassing way for at least the last two millennia in our Judeo-Christian civilisation. 
Desire would have become the "buzzword" for a cultural situation where freedom has been redefined as "a sort of ceaseless mobility whose only enemy is that of limit" (Eagleton 1997: 268). Certainly, in postmodernity there would be "no rules, only choices", allowing everyone to be anyone (Featherstone 2007: 81). Postmodernity is the time for lifestyles, "the characteristic mode of sociality of the consumer society" (66). In this regard, "the ludic dimension of consumption has gradually supplanted the tragic dimension of identity" (Baudrillard 1998: 192). Hence, identity becomes "makeshift" (Clarke 2003: 151). It is in this way that postmodern individuals manage, if primarily in a formal, superficial way, to "impose some degree of continuity onto their individual life-experiences" (165). This is why postmodern, urban nihilism can be thought to be a "happy nihilism" of sorts, "a relief from the burden of finding yourself as the goal of life". Under this dispensation, built upon individualism and consumerism, "you are either in or out", and to search for a meaning in life or History would definitely be "out" (Silverman 1999: 49, original emphasis). A few years after the publication of Crash, in the wake of the neo-conservative revolution led by Ronald Reagan and Margaret Thatcher, the "happy nihilism" of a growingly dual society based on consumption and communication will harden into a "society of exclusion", if it remains a society at all. In it, social conflict has been repressed and eventually done away with. ${ }^{4}$

\section{EMPTINESS AND STASIS: POST-HISTORICAL PRESENTNESS}

This is what happens when all there is left to sustain one's dreams in life is consumerism (Naughtie 2014: 481). The situation and its diagnosis, moreover, are one and the same then and now: "disbelief in any metaphysical world" (Nietzsche 1968: 13). A significant outcome would follow: the questioning of all kinds of authority.

Hence, J.G. Ballard can recognise the moral authority of "the past" as "the main casualty of World War II", Auschwitz having "irrevocably breached any meaningful alliance" between the past and the human condition (Langer 2003: 12). This would be the real start of postmodernity, which would consist in an infinite, unchanging present lived by everyone. This present would absorb the past, the future and any hopes related to the latter in a simultaneous point of time characterised by stasis, the dictatorship of the everself-same, that situation where scientific and technological, although not necessarily human "progress becomes routine" (Gasiorek 2005: 109, 175; Vattimo 1987: 14, my translation, original emphasis). Under this post-historical dispensation, novelty would be merely that which would allow things to go on the same way (13, my translation). The future is today: already in his 1995 introduction to the novel, J.G. Ballard had written how the future was "ceasing to exist, devoured by the all-voracious present" (2008: n.p., par. 2). In Emil Cioran's terms, "the idolatry of tomorrow" is definitely deceased (1970: 47).

In the end, the major cause behind Ballard's joining Vaughan's cult is none other than postmodern nihilism, another name for post-historical emptiness, the condition under whose heavy burden Westerners have been wandering "like aimless Saturday crowds

4 In a 1987 interview, Margaret Thatcher, after eight years in 10 Downing St., makes what follows very clear: "They are casting their problems at society. And, you know, there's no such thing as society. There are individual men and women and there are families" (Keay 1987: n.p., par. 30, my emphasis). 
through the great supermarket of life" since some moment not much later than the end of WWII (Zinik 2014: 363). As the author states in an interview: "There's nothing to believe in now". Even the "consumer society" may have "come to pass", leaving us only a sense of "nagging" emptiness (Barr 2014: 287). This being so, all available means of transcendence are exhausted. All that is left is an unbearable "proliferation of ourselves", a true "hell of the same" (Sage 2008: 34). Under these conditions, lacking in purpose and meaning, everyday life can only be "an atrocity" (Weiss 2014: 458).

\section{SELF-TRANSCENDENCE, VIOLENCE AND THE DEATH DRIVE}

Characters in Crash can be described in terms of their will to escape a nihilistic existence that, as Nietzsche already perceived, "has no goal or end" (Nietzsche 1968: 13). Their will is one to transcendence of our existential limitations: space, time, matter, consciousness and subjectivity. In an interview, J.G. Ballard recognises himself to be a firm partisan of self-transcendence understood as the destruction of self, thus going beyond the "enormous limitations" of our sense of self and our physicality, thereby opening up to "a larger world" (Rønnov-Jessen 2014: 207).

The risk implicit in this destruction of the self is unwittingly opening up to a larger nothingness. Hence, that Crash is not a fairy tale, but a story marked by negativity, is clear from its very first sentence: "Vaughan died yesterday" (Ballard 2008: 1). From then on, we will be thrust into a bizarre trip down the dark alleys of the human psyche with a final, unavoidable, fatal destination: the death drive.

In the eternal struggle between Eros and Thanatos that, according to Sigmund Freud, determines the evolution of human civilisation and constitutes the main tool for the survival of the species, the members of Vaughan's symphorophiliac circle would clearly be on the side of death and its related "natural" instinct of aggression, characterised by the hostility of each against all and of all against each (Storr 2001: 68). Hatred would thus prove Freud to be right in his contention that this instinct is older than love in our species (65). Therefore, although both instincts have equal status, death is the biological telos of life, and the death drive is the first instinct to have developed in animate matter (Freud 2003: 78-79). In Crash, this would be even more so, as its characters happen to come across a charismatic leader christened with blood and semen at a time of utter socio-political and cultural anomie. Positivities are nowhere to be seen in Crash.

Despite his many affirmations to the contrary, J.G. Ballard must be considered an anthropological pessimist (e.g., Dery 2014: 340). He would subscribe to T. W. Adorno's words: the writer may have "to work one's way through the darkness without a lamp, [...] and to immerse oneself in the darkness as deeply as one possibly can" (2000: 144). Some unsavoury findings could be made by following this underground method: to begin with, that we humans may not be the "sane, sensible" creatures we believe ourselves to be; that we may not have to "descend" very deeply to come across "parts of ourselves that are not fully sane"; that "just below the surface" there is in us a "potential for violence" which is "extremely great"; and thus, finally, that there might not be any "innate decency" in the human race (Gray 2014: 378-79; Litt 2006: 424). According to J.G. Ballard, the more 
science advances in its understanding of the human being, the more we have to face our "taste for cruelty, for the subversive, for the deviant, for the perverse" (Gray 2014: 380).

Driven by repressed psychopathologies and always refusing to be tamed, the "human animal", the "beast" would be closer to the average chimpanzee "on a hunting party" than to the heirs of any humanist tradition or the "civilised inheritors of the [...] Enlightenment" that Westerners take themselves to be. In the end, we have to consider that such an anticivilised attitude befits a species whose evolutionary history has been red in tooth and claw for most of its presence on the surface of this planet. In the words of one of the characters in Super Cannes, one of J.G. Ballard's late novels, "homo sapiens is a reformed hunter-killer of depraved appetites [...] with a taste for cruelty and an intense curiosity about pain and death" (quoted in Gasiorek 2005: 192). Violence and sex, especially if perverse and opposed to normative cultural superstructures such as religion or ethics, are thrilling in themselves; when associated with the death drive, and in combination with the feeling of power, they may prove irresistible, regardless of the injunctions made by the reality principle to prevent the expression of a long pent-up savagery.

Thus, it can truly be said that Vaughan gives the members of his cult, in Ballard's words, what they most want and fear (Ballard 2008: 76). In the end, Ballard has to confess to getting "locked into a system of beckoning violence and excitement" (142). This system is embodied by the motor car, the machine that allows humans to feel overwhelmed by the "simple and ingenuous pleasure of being in the centre of so much power, so much speed" (Inglis 2005: 200, my emphasis).

\section{BODY OVER SOUL: ABJECT SELF-TRANSCENDENCE}

The unconscious, common to the species and probably the most significant, if nonmaterial, component of the untamed human animal, would be, in the form of irrepressible psychological energies and drives, the true source of any wish to reintegrate ourselves into what we feel to be a lost primordial unity of being. In Crash, these energies are experienced by the narrator as a sensual awakening to an up to then unknown dimension beyond Ballard's anodyne everyday routine, beyond what we could call his "postmodern autism" or the "coma of wellbeing". It is an "uncanny", Lacanian "lost body", forgotten in the wilderness of the unconscious after overgrowing, but also repressing it in our psychosexual development towards maturity and adulthood, that Ballard unexpectedly finds and experiences. This body beyond our conscious memory returns and is revealed under the violence of his accident (Dery 2006: 235). Consequently, his attitude, even while still at hospital, is one of "relief" after his only "real experience" for many years, suddenly and unexpectedly set “in physical confrontation” with his own body (Ballard 2008: 28). This experience would validate Nietzsche's historically against-the-grain conviction that "belief in the body is more fundamental than belief in the soul" (Nietzsche 1968: 271). Despite the violent and perverse elements to be found in Crash, its main characters seem to believe, at least unconsciously, that the "senses five" may certainly be the key to an entirely new, potentially redemptive "world of delight" (Blake 1994: 9). In this world, meanings and "mysterious connections" would be read off the surface of things, most prominently the human body. This is what Ballard does, for example, when wildly speculating about the sexual life of the nurses 
taking care of him in hospital on the sole basis of the contours of their hips or breasts. In this respect, what is attempted by the otherwise very nihilistic characters of Crash, most notably its narrator, is to get back to a sort of ontological Eden beyond our limited and flawed existence as humans, for this existence is felt to be mere illusion. As long as we do not rise over our existential limitations, we will be "fallen beings in a fallen universe", victims of what Gregory Stephenson considers to be the "central theme" in J.G. Ballard's oeuvre: "ontological disorder" (1991:147).

Most clearly, it is not any disembodied spirituality but the sensory, bodily and actually abject that plays a pivotal role in the characters' attempt to escape from a culture of overpacified, sedated, meaningless superficiality. Abject indeed are their bizarre methods of self-transcendence, which originate in a rare paraphilia that brings death and eroticism together, as though it had been imagined by Bataille himself: symphorophilia (Reader 2006: 60). They actually cultivate and actively court catastrophe, culminating in arranged car crashes as sexual stimulus and means of self-transcendence.

In his confused and probably unconscious search for meaning, self-transcendence and spiritual deliverance, Ballard turns to Vaughan, the epitome of the mad scientist character turned into a postmodern guru, "messenger" or prophet (Ballard 2008: 86). In so doing, the former follows what he describes as his "messianic obsessions" and is even aware of Vaughan being a projection of his own "fantasies and obsessions", conjuring him up as his personal avenging angel. His initial accident, therefore, might have been a mere excuse for their encounter $(50,181)$. In any case, by following him Ballard chooses to follow a very peculiar sort of saviour: one dominated by a clearly obsessive and particularly bizarre type of sexual psychopathology.

In his reckless authenticity, negating the value of an administered, sanitised existence, Vaughan could also be seen as a sort of postmodern avant la lettre: according to Lyotard's early thought, a representative of the unrestrained intensities of the libido as an unconscious, incontrollable and unpredictable, purely affirmative force beyond any possible lack or deferral (Woodward 2009: 188-91). This kind of unrestrainable, irrational life affirmation is perhaps behind Ballard's use of the same expression, "without thinking", no fewer than seven times throughout Crash when describing his reactions and experiences after his initial accident; it is used yet an eighth time in relation to Catherine, his wife, and her getting "excited" by being chased by Vaughan on the road (Ballard 2008: 91).

In this, they remind us of Camus's reticence against reason: an existential, absurd hero, according to the French writer, must live with total "indifference to the future"; in the words of Miguel de Unamuno: "the true future is today" (Camus 1991: 43; Dienstag 2006: 136). "Life is not to be built up but burned up. Stopping to think and becoming better are out of the question" (Camus 1991: 99). Sartre seems to be glossing on this when he portrays "explicit reflection" as marked by "internal division, conflict, and frustration", being the key to "a world of solitude, disengagement, isolation, and alienation", "a world of exile where something is always missing" (Wicks 2003: 43-44). In the end, "reason is the enemy of life": "everything vital is irrational, and everything rational is anti-vital". All that consciousness avails is nothing but "death-in-life" (Dienstag 2006: 126). In joining Vaughan's cult of reckless irrationalism, Ballard's deepest wish will be that of the rest of 
its members: to learn who he really is in the proximity of death. They will all hold on to a last chance for meaning, if inarticulate and brutal, in their existence.

\section{NIHILISTIC TRANSCENDENCE: PRIVATISED MADNESS}

In Crash, regardless of the seeming paradox, we are placed in front of a very complex sort of nihilistic transcendence: one towards nothingness. Regarding this, a very problematic side of Vaughan would be precisely his association with the death drive. Indeed, by scorching the land and burning all bridges behind him, as exemplified in his failed suicide-assassination, it is implied that Vaughan's active nihilism eventually becomes a complete one. Complete nihilism could be defined as the belief that there are no transcendent values whatsoever to be grounded on anything at all, and that anyway they are not necessary for any kind of valuation: in the end, life would be valueless (Woodward 2009: 39-40). After Vaughan's demise, all that remains is Ballard's premonition of his own death in a crash, leading nowhere except to the same void that Seagrave's pathetic suicide already left behind itself. ${ }^{5}$ From this point of view, that Seagrave's corpse is described as "at last escaping out of this uneasy set of dimensions into a more beautiful universe" can only be construed as helpless sublimation, macabre sarcasm or a symptom of what by this time should be called Ballard's psychosis (Ballard 2008: 185, 152). ${ }^{6}$ Even Lyotard, later in his oeuvre, recognises the need for structural consolidation to work alongside the destabilising effects of the death drive in order not to conserve nihilism. Thus, the death drive would now be related to structures rather than just their dissolution through the release of libidinal energies. Ever seeking out "new intensities" may just lead to a "suicidal passion" resulting in the destruction of existing structures that would allow for the expression of intensity by themselves or by their connection with others. Turning to Deleuze and Guattari's terminology, we could say that certain lines of flight are always in danger of becoming lines of death (Woodward 2009: 193, 237-38). ${ }^{7}$ Lacan, who believes heroism to consist in pursuing the lost object whatever the cost, never giving up on your desire, understands this aim as inextricably intertwined with the death drive, which can be dangerous, if not fatal (Belsey 2002: 91-92). Disguised as a warning against certain evils of modernity, Crash is ultimately a "psychopathic hymn" (Self 2014: 309).

5 Seagrave will eventually commit suicide by car crash dressed as Elizabeth Taylor (Ballard 2008: 152).

6 Actually, J.G. Ballard constructs this scene by following a modern literary trend, going back as far as de Sade, where representation of death is often linked to a desire to shock, exploring it, in the wake of Bataille, as "a site of defilement and excess" (Noys 2005: 102). In this way, modern art, in its passion for the real, would be "the art of death" (103).

7 This is precisely Robert Wicks's reason for his criticism of Deleuze and Guattari's efforts to find a principle of "freedom from oppression" in the unconscious, as this search most probably leads to the loss of the "integrated self" that he believes to be fundamental to enjoying conscious freedom as "a distinct and autonomous individual" (2003: 277).

"Lines of flight", a theoretical concept coined by Gilles Deleuze in his work with Félix Guattari, is defined by Dino Felluga within their idea of "assamblages", as "movements of deterritorialization and destratification" in any of their components, understood as libidinal flows. They would be "centrifugal forces" making assamblages burst outward (Felluga 2015: 24, 35). 
Quite clearly, the author does not regret the state of affairs behind his fiction, in spite of its risky, technologically nightmarish potential. If anything, he celebrates it: in his opinion, in the inane, consumerist society we are living in, one which is completely committed to sanity in all spheres, the last refuge for the free mind would be madness. He incontrovertibly states: "anything is better than being sane" (Baxter 2008a: 124). Within this frame, even Vaughan, Crash's "psychopath as a saint", may stand for a "nature reserve", that of psychopathy as "a last refuge for a certain kind of human freedom" (Delville 1988: 85). Deviance, then, understood as perversion endorsed and mediated by technology, has to be thought of as the only remaining "freedom of the spirit" (Vale 2014: 154). In other words, the only available refuge from performativity and consumerism would be in one's private imagination, in the domain of solipsistic, technology-fed and -driven obsessions.

This analysis is not very far away from Julia Kristeva's when considering madness as our present "milestone", which she does in her analysis of Marguerite Duras's L'amant. According to her, the heavy weight of the unreal, new suffering "world of death" we all have to shoulder has its cause in the "massively, in totalitarian fashion, social, leveling, exhausting" modern political domain. In her view, private suffering would absorb "political horror into the subject's psychic microcosm" (Kristeva 1982: 4, 234-35). In this way, the suffering subject would become "the site of the uninterrogated significance of the deepest moments of collapse of modern institutions and discourses" (Beardsworth 2004: 160). As a result, "madness is a space of antisocial, apolitical, and paradoxically free individuation". This madness would be just the exacerbation of a retreat towards the private, which is "emphasized to the point of filling the whole of the real and invalidating any other concern" (Kristeva 1982: 4, 235). In other words, if up to J.G. Ballard and Kristeva's time a free Englishman's home was his castle, in Ballard's troubled suburbia of postmodernity it is his autistic Shangri-La, where to get disconnected from the rest of the universe as a source of confusion and suffering. In this way, maybe since the 1960s, there has been a constant "retreat from the social into an idealized version of the household and everyday life as a form of 'privatization' of the individual around consumption", eventually "the sole remaining value". ${ }^{8}$ Not in vain does postmodern society think, speak and consume itself "as consumer society" (Baudrillard 1998: 193).

This would be the last stage of a larger development whereby people have been turning to the private sphere and the values traditionally related to it as the ever more exacting public domain has become more and more deprived of meaning for them. There has been a growing de-institutionalisation and privatisation of the individual and their "fundamental project", "the predominance of individual rights over collective obligations" having been asserted more and more vehemently (Silverman 1999: 136; Lipovetsky 2000: 202). Morality would also have become an increasingly private affair till its implosion in the post-WWII society of plenty: at the end of "the era of cold, impersonal, distant duty", there has been an unequivocal rejection of "the disciplinary society of "the age of morality" (Eagleton 2007: 22; Lipovetsky 2000: 123; Lipovetsky, as cited in Silverman 1999: 140). Powered by "compensatory dreams", consumerism may well have taken over from disciplinary power,

8 Although this hypothesis has been put forward with regard to France, I find it fully applicable to Ballard's Britain (Silverman 1999: 137). 
thus becoming invested with "a force equal, if not superior" to the latter's. By "enlisting the "pleasure principle" in the service of the "reality principle"," desires are harnessed to "the chariot of social order"; by the same logic, "presumably invincible irrational human wishes" are turned into "guards of rational order" (Zygmunt Bauman, as cited by Clarke 2003: 145, 155).

\section{SEXUAL REGRESSION: PERVERSION AND INFANTILISATION}

With respect to perversion in Crash, leaving aside its enhancement by technology, its origin has to be sought in the main characters undergoing what in Freudian terms must be described as a process of fixation or even psychosexual regression to an infantile stage. This will make bisexuals or homosexuals out of them, or will subject them more generally to different types of paraphilias or other aberrant forms of sexuality: homosexuality, masochism, exhibitionism, voyeurism and fetishism would be among the commonest ones (Storr 2001: 30; Thurschwell 2000: 44). Just like children, characters in Crash can be seen as polymorphously perverse: wanting to make everything and everyone a part of themselves and their immediate world. This would be so even despite their being married in a number of cases (the Ballards, Dr. Remington and Seagrave).

In Crash, all major characters lack or reject any inhibiting mechanisms related to sexual maturity. These would allow to proceed from "the subjugation of impulse to the control of intrapsychic restraint", ultimately leading to "deferred gratification and tolerance of unpleasure" within a long-term sexual strategy (Thomas 2011: 335, 337). For instance, while both Vaughan and Catherine Ballard are promiscuous bisexuals from the very start, Helen Remington becomes more and more of a lesbian; Seagrave, in his turn, dies in drag attire, disguised as his master's obsessive target, Elizabeth Taylor (Bristow 1997: 76). Deprived of or unwilling to acknowledge the "psychic dams" that, according to Freud, are required to lead an adult, functional sexual and affective life (that is, shame, loathing and morality), they will remain "eternal children", keen on "immediate gratification" and totally disregarding the consequences thereof (Thomas 2011: 359).

Furthermore, some secondary characters are also described as sexually perverse (in a Freudian reading) in several diverse ways, such as "sadistic charge nurses" or "lesbian supermarket manageresses" (Ballard 2008: 7, my emphasis). These initial pages set the tone for the rest of the novel: one of "unrestrained hedonism" and dysfunctionality regarding adaptation to a socially controlled, mature sexuality (Thomas 2011:338). Finally, we must not forget that both in Freudian and Kristevan psychoanalytic theory, "infantile, perverse, polymorphic sexuality" is "always already a carrier of desire and death" (Kristeva 1982: 38).

As for Ballard, while he recovers in hospital from the injuries caused by his first accident, he undergoes an unexpected resensitivisation of what he himself calls his "most infantile zones" (which I would extend to his mind - Ballard 2008: 22-23). He eventually evolves into bisexuality, at least in his relationship with Vaughan $(70,81)$. Within a psychoanalytic framework, in all these anomalous, immature, perverse behaviours I have described, the main characters are also privileged representatives of the infantilisation of the contemporary world that the author refers to in his 1995 introduction to the novel: "we live in an almost infantile world where any demand, any possibility [...] can be satisfied instantly" (Ballard 
2008: n. p., par. 2). As J.G. Ballard wrote in his 1974 "Introduction" to the French edition of Crash, "the main fact of the 20th century is the concept of the unlimited possibility" (Ballard 1974: n.p., par. 3).

This sexual regression finds its most relevant instantiation in Vaughan. Indeed, Vaughan is above all a narcissist, as he is fixated on the identification of a not yet externalised sexual object, namely himself; narcissism implies moreover a comeback to one's self as a "self-contemplative, [...] self-sufficient haven" (Freud 2001: 103; Kristeva 1982: 14, my emphasis). More generally, Vaughan's narcissism is also related to abjection, as abjection is considered to be "a kind of narcissistic crisis", while also being its precondition (Kristeva 1982: 13-14, original emphasis).

The most notorious example of regressive, abject perversion in the novel, however, takes place during Ballard's visit to Seagrave's home, where the stunt driver pretends to breastfeed a little son of his (Ballard 2008: 83). This last behaviour is most typically illustrative of abjection, the very rock bottom of human sexuality: in Seagrave's outrageous gesture, he embraces primal, motherly femaleness to the point of surrendering his symbolically male, fatherly identity to the ideal of a renewal of the pre-symbolic. ${ }^{9}$ In this way, he links up with the indistinct, in practice infinite mother the newborn baby feels to be just a part of. In terms of the language the author uses in this episode, the mention to Seagrave's "nipple" and the implied reference to milk, the motherly fluid per excellence and one of Kristeva's paradigmatic embodiments of abjection, highlight this rejection of what Lacan calls the phallus and its connection with fatherly authority and social functionality (Kristeva 1982: 2-3). This must be linked to what Kristeva terms "the pitiful power of the feminine" in a masculinist culture such as the West's, as it can be "unleashed only with the help of masculine degradation", or the "bankruptcy of the father and manly authority" (169). What this all ultimately points to is the relationship obtaining between the perverse and abjection: "the abject is perverse because it neither gives up nor assumes a prohibition, a rule, or a law; but turns them aside, [...] uses them, takes advantage of them, the better to deny them" (15, my emphasis).

Here, J.G. Ballard, who also sees abjection as aligned with innate perversion within Freud's depth psychology model, goes beyond him, as he relates Oedipal conflict not to the superego, the ultimate moral referent and the site of the symbolic law of fatherhood, but to the id, the unconscious repository of the love and death drives and instincts. This is not so strange, though, since both the ego and the superego are but outcrops or offshoots of the id, the primal substratum of all consciousness, the oldest, primitive, unorganized, and emotional part of the mind, in which time has no saying, from which the other structures are derived and which we share with animals: "the realm of the illogical" (Storr 2001: 60; Dienstag 2006: 91). Governed by the pleasure principle, it does not recognise any values, good and evil or morality, and only by keeping it repressed can we form and keep our own

9 In Lacan's version of psychoanalysis, sexual maturity only comes after acquiring language, which introduces the subject into what he calls the symbolic order. The symbolic order, according to Lacan, is shared by all subjects, can be identified with language and the law, and provides a social and intersubjective field of signification "where everyone has access to the pronoun 'I"" (Bristow 1997: 91). Prior to that, the child would live in a pre-symbolic, imaginary order, where the boundaries of its clean and proper self would not be clear and distinct yet, its body being experienced as part of the mother's (Homer 2005: 31). 
proper bodies and selves, the very touchstone of our human condition (Storr 2001: 61; Freud, as quoted in Wicks 2003: 12). Thus, Vaughan stands for a viciously unchained id that will not obey any call for delayed satisfaction of instinctual needs. He goes beyond that point where we can be considered functional human beings.

Secondarily, this sexual atmosphere speaks of a time of ethical anomie, in which even gender standards are blurry and uncertain, and things such as the use of children in the playing out of sexual fantasies, or their parents' responsibility towards them, do not seem to be major ethical concerns.

\section{ABJECT TRADITION AND THE PERVERSE BODY: POSTHUMANITY, ABHUMANITY AND TERATOLOGY}

A fundamental characteristic of J.G. Ballard's writing is that it belongs to an abject tradition, both in French (Sade, Bataille, ... despite his unlikely claim that he has never read them) and in English (Burroughs - whose influence he has contradictorily denied and acknowledged, depending on the occasion - or Henry Miller: Delville 1988: 41; Gasiorek 2005: 93). ${ }^{10}$ Instead of modernism's purity and geometry, Ballard's (arguable) postmodernism is one that drips blood and semen, just like the still warm corpses of car-crash victims in the novel. J.G. Ballard's is a poetics of abjection, placed between "extremes of baseness and spirituality", and reaching "borderzones of identity" (Gasiorek 2005: 92; Ballard 2008: 36; Delville 1988: 40-41). In Crash, characters are discontinuous, fragmented, fluid selves who often go beyond the condition of res cogitans in their Bataille-like cultivation of waste and "unproductive expenditure", always "without the least concern for a goal or objective, and, therefore, behaving without any meaning" (Delville 1988: 85; Jenks 2003: 101). They inhabit a dimension all of their own where the imperatives of Georges Bataille's "general economy" (the name he gave to his impossible system of thought based on the notions of waste, squandering and destruction) ground their existence in "the need (...) for destruction and loss" (Reader 2006: 77, my translation). There, where life is a potlatch, where "the human tendency to expend rather than conserve" is acknowledged, they can lose themselves from themselves (Delville 1988: 52; Stoekl 1985: xv).

In this light, Vaughan appears as an all too organic character, a zombie-like figure out of one of Francis Bacon's most extreme painterly nightmares, a sausage-man inflated by all sort of rancid fluids, unwilling to lead a sanitised life: the personification of Bataille's "vulgar materialism", the living evidence of the "the contingent, messy, irreverent and residual nature of our own world" (Gasiorek 2005: 139; Depper 2008: 62; Baxter 2008b: 521). In this sense, maybe the most notorious scene in the entire novel is that of Vaughan's sodomisation by Ballard. Here, Vaughan's scarred body is described in terms of blood, semen and urine, and is ultimately compared to that of "a deranged drag queen revealing the leaking scars of an unsuccessful trans-sexual surgery" (Ballard 2008: 166, my emphasis).

The perverse implications of homosexuality are associated with references to paradigmatically abject substances, as when Ballard describes Vaughan's penis, which

10 For Ballard's points of coincidence and indebtedness to this abject or irrationalist tradition, see, e.g., Delville 1988: $36,41,87$. 
he winds up fellating, in terms of its "faint odour of a woman's excrement clinging to the shaft" (ibid.). Once anal sex is consummated, the chapter ends with the he abject image of yet more semen, this time Ballard's, leaking from Vaughan's anus (ibid., my emphasis). All of these fluids and substances stand for the abject, as they represent "for the subject the risk to which the very symbolic order is permanently exposed": a falling back into the motherly, feminine and pre-symbolic. They are also related to the very idea of boundary (of the clean and proper self, to begin with) and therefore also to both psychosexual and socio-cultural margins and marginality (Kristeva 1982: 69). Indeed, the principle that only female bodies leak founds and sustains "phallocentric culture" in its "attempts to erase and purify the paternal body" (Reader 2006: 36).

In this light, Vaughan is marked by a particular kind of abjection, linked to semen. This fluid, with which he is constantly associated, would be in sharp contrast with what always appears to be a predominantly phallic kind of sexuality dominating the novel. Quite clearly, the sexual subtext of Crash privileges the male as phallic, hard, penetrating and dominating. Thus, for example, all wounds, when it comes to sexual matters, are seen as invaginations, and whichever the vent, the sexual act is always one of penetration (Harpold 1997: n. p., par. 18). Semen, on the contrary, is a soft, sticky substance, amenable to other instances of the soft and wet that are quintessentially female, as is the case with menstrual blood or vaginal mucus (ibid.). ${ }^{11}$ Yet, a minimum of space for "the wet spot" in the novel allows Vaughan to be seen as subversively standing against phallus supremacy (ibid.). Thus, regardless of Ballard's situation after Vaughan's death and his resolve to die in a car crash himself too, the latter is literally abjected, just like human waste, only to confirm the phallic impenetrability of the new, posthuman cyborg that Ballard represents (Iocco 2007: 51). It would be "only by excluding men's bodily fluids from their self-representations and controlling those fluids through various forms of solidification that men can mark their own bodies as clean and proper" (Reader 2006: 45). There would be widespread "masculine aversion to the soft, the liquid, and the gooey" as associated with "the monstrous feminine". In the end, they would stand for "feared libidinal energies [...] not beholden to reason", hence always posing a threat "to wash away all that is rational" and therefore masculine (Bukatman 1993: 303, my emphasis).

Another instantiation of the soft as feminine, irrational and worthless would contribute to underline Vaughan's abject condition: his aforementioned anal penetration by Ballard. As Camille Paglia points out: "Sodomy is imagined as ritual entrance to the underworld, symbolized by man's bowels" (2001: 246). This would agree with the confirmation of Ballard's masculinity, as opposed to Vaughan's, through his fantasy of having a "metal body" during a ride with his wife, and also with his futuristic description of her and Vaughan, while they are having sex in Ballard's car in his presence, as "two semi-metallic human beings of the distant future making love in a chromium bower" (Ballard 2008: 90, 133).

Finally, Vaughan's scars are also signifiers of abjection, as they make visible "the alteration of the self and clean into the defiled" (Kristeva 1982: 84). As abjection, in a Christian cultural context, is related to sin in that the latter is construed as individualised

11 Despite the fact that Kristeva herself does not include semen in her catalogue of typically abject bodily substances (Harpold 1997: n. p., par. 16; Kristeva 1982: 71). 
abjection, scars could also be seen as constituents of a perverse, material and sinful body, purely "eager drive confronted with the law's harshness", being therefore in sharp contradistinction with a subdued, sublimated one, after its reconciliation with the law (124-25, 127-28).

The portrayal of the aftermath of anal sex and acid intoxication in Crash brings things to a descriptive abject climax reminiscent of some extremely delirious painting by Max Ernst or worthy of any sequence in Bunuel's Un chien andalou or L'age d'or. The scene in question, which does not spare mention of Vaughan's limping testicles, finishes with a memorable image: the flies swarming "in thick clumps" around Vaughan "as if waiting for the rancid liquors distilled from the body of a corpse" (Ballard 2008: 168, my emphasis). This is not only an animalistic reference to sexuality and death, here underscoring a previous comparison between Vaughan's tongue to that of a reptile, but also the key to the novel's discursive core: the fusion of Eros and Thanatos, life lived to the extreme in pursuit of liberating death, which is ciphered in the abject object par excellence, the corpse (82). Vaughan's abjectification takes place after a sudden revelation that will make him drop his previous successful career for the sake of the transformative potential he senses in disaster, even if it will make him embrace death, as it occurs to many other characters in Ballard's fiction (Baker 2008: 15, 17; Huntley 2008: 29). Eventually, his very death will be an example of Bataille's irresistible, hideous, transgressive, abject, "bloody death": one worthy of a self-sacrificing god who would carry "to the very end what ordinary men are happy to dream about" (Bataille 1985: 69, my emphasis).

Linking up with what was said above on the relationship between body as drive, sin and the abject, Vaughan might still be seen as an abject, pagan St. Paul: blinded by the dark light of abjection and having fallen off the horse of his scientific education and mediatic career, he sets off on a path of salvation, guided by the mystery of the abject sacrament whose object is wounded, mutilated, sacrificial flesh, namely the car crash. Thus, from being originally "a source of evil and mingled with sin", abjection now "becomes the requisite for a reconciliation" and "a source of health": a new Eucharist, an instrument of salvation. By cultivating his perversions under a deviant imperative of "unlimited, nonproductive expenditure" and "free play", Vaughan approaches a "quasi-mystical state" generally associated with ecstasy and the sacred (Jenks 2003: 100). This would also explain Vaughan's messianic charisma and his admittance of other penitents as devoted disciples and apostles in his new church.

Outright abjection is concretised throughout the novel in actively sought pain, mutilation and fantasised death as instruments of self-fulfilment in perverse sexual ecstasy. An early example thereof is rendered by the narrator while still in hospital, when he relates an old dream in which his wife gives birth to a "devil's child" among liquid faeces spurted from her breasts. This shocking image is nonetheless still called a "nightmare" by him; by the time Vaughan has had sex with Catherine, Ballard's abject musings and practices have gone far enough to think of Vaughan's pale, greasy, scarred body as an ideal of "mutilated beauty" (Ballard 2008: 22, 141). In between, in just a few pages he regales us with a catalogue of demented fantasies of both Vaughan's and his in which horrific, "insane" wounds and an almost complete catalogue of bodily fluids play a leading role, along with fellatio, incest and even decapitation, only falling short of coprophilia. 
Towards the end of the novel, we come across an especially vicious climax of abjection in a number of fantasies awoken in Ballard's mind. All of them pick up some of the elements we have just paid attention to. Thus, by the time he is having an ultra-abject affair with Gabrielle, he goes into a sort of delirium involving the same proliferation of "orifices" that he finds in the wounds scattered all over her body as a result of her accident, which become instrumental in the consummation of their encounters as so many new vaginas and anuses. Later on, following Seagrave's already described abject breastfeeding habits, Ballard has a number of explicit, appalling fantasies of a paedophilic nature. Finally, some of these motifs come together in a fantasy of incest with his own mother, covered with sexual orifices all over, whose demented character can only remind us of Bataille or de Sade, thus confirming the female body as "primarily a site of abjection" or "an active site of transgressive horror" (Rønnov-Jessen 2014: 205; MacGregor 2006: 103-04). ${ }^{12}$ The fact that it is Ballard's mother that he dreams about is also meaningful, as it underlines the difference between female and male. Men are not deemed to have leaking orifices, as we saw above, in order for them not to be considered as abject as women in our patriarchal, phallocentric culture; and among the latter, the leaking female par excellence is the mother (Reader 2006: 48). This last fantasy amounts quite simply to a perverted positivisation of abjection, a frenzy of cultural subversion in which everything is turned upside down. In this way, it involves a return to a protean, morally indifferent sexuality in which any distinct social role assumed through the process of psycho-social growth into the symbolic order is actively rejected, if not directly mocked.

An abhuman element is strongly suggested in Crash. Here, we are treading on teratological or monstrous territory. Two main examples could be put forward: the first one would be the abject fantasy of a Golem-like "homunculus", made out of "blood, semen and engine coolant", during one of Ballard's sexual encounters with Dr. Remington. These are almost the very same abject fluids mentioned in order to describe the reek coming from Vaughan's crotch somewhere else in the novel (Ballard 2008: 63, 81). The second example has as its object Ballard's preference for Gabrielle's "deprived orifice", a deep wound in one of her thighs, during intercourse, foretelling abhuman sexual mutations in the fashion of "templates for new genital organs". No wonder, Ballard is quite characteristically disappointed on realising that her breasts are not prosthetic (146-47).

\section{CONCLUSIONS}

This essay studies, from a psychoanalytic and sociological standpoint, the issues of postmodern nihilism, its transcendence or overcoming, and abjection in J.G. Ballard's Crash. The origin of postmodern nihilism, contended here, is related to ethical anomie and unbelief in metanarratives. This nihilism, in that it derives from the economic imperative and therefore from the contraction of the social and axiological to performativity and profit in a free market, is of a reductive kind. The only values existing outside this neo-nihilism, intimately linked to capitalism, would be relative and transitory, linked to small communities, such as the symphorophiliac cult presided over by Vaughan in J.G. Ballard's novel.

12 In 1997, though, he implies that he has finally read de Sade, at least (Dery 2014: 345). 
Among the effects of this reductive nihilism we find, firstly, universal commodification and what J.G. Ballard calls the "suburbanisation of the soul": a colonisation of the social and the individual psyche by the dictates of the supermarket culture. This happens in the context of a rampant consumerism and a "happy nihilism" where self-realisation is out of the question: goals or ends do not count for postmodernity. Secondly, people live in stasis, the past and the future having been conflated into a post-historical, unchanging, routine presentness. The only way to overcome this dead-end situation would be the free adoption of lifestyles and their associated value systems; in a society of exclusion, however, where lifestyles are pre-packaged and available for cash, thus determining whether you are either in or out, this is no solution.

This is the context where Vaughan creates and leads his deviant cell, bent on overcoming their existential limitations and the ambient, postmodern ontological disorder. Their main allies would be the automobile and the exercise of a protean, infantile, affectless and conceptualised sexuality. In so doing, though, they will only be trying to enact their own sick fantasies and will only achieve a glimpse of an inborn violence, cruelty and perversion in the human being. In that they cultivate a rather disturbing and dangerous paraphilia, namely symphorophilia, their ultimate guide will be the death drive. Therefore, their attempt at self- knowledge and self-realisation will ultimately consist in the near-death of bodily harm or mutilation, or simply death, as in Vaughan's and Seagrave's suicides. Behaving in such a recklessly irrational way and unwittingly considering, according to J.G. Ballard's terms, that madness is the last refuge for a free mind in postmodern society, they bring abjection and nihilism together. In so doing, they finally reach the completion of nihilism: the belief that there is no need for any transcendent values to be grounded on anything at all. For them, life is simply valueless.

\section{REFERENCES}

Adorno, T. W. 2000. Metaphysics: Concept and Problems. Stanford, CA: Stanford University Press.

BAKER, B. 2008. “The Geometry of the Space Age: J.G. Ballard's Short Fiction and science Fiction of the 1960s". J.G. Ballard. Ed. J. Baxter. London and New York: Continuum. $11-22$.

BALlard, J. G. 1974. "Introduction to the French Edition of Crash". 31 May 2017. http:// imagesoferoticism.com/jg-ballard-introduction-to-crash-1974/.

Ballard, J. G. 2008. Crash. London and New York: Harper Perennial.

BARR, L. 2014. "Don't Crash". Extreme Metaphors: Selected Interviews with J.G. Ballard, 1967-2008. Eds. S. Sellars and D. O’Hara. London: Fourth Estate. 283-90.

Bataille, G. 1985. Visions of Excess: Selected Writings 1927-1939, Minneapolis: University of Minnesota.

Baudrillard, J. 1998. The Consumer Society: Myths and Structures. London and Thousand Oaks, CA: Sage. 
BaXter, J. 2008. “Kingdom Come: An Interview with J.G. Ballard”. J.G. Ballard. Ed. J. Baxter. London and New York: Continuum. 122-28.

BAXTER, J. 2008. "Radical Surrealism: Rereading Photography and History in J.G. Ballard's Crash". Textual Practice 22,3: 507-528.

Beardsworth, S. 2004. Julia Kristeva: Psychoanalysis and Modernity. Albany, NY: State University of New York.

Belsey, C. 2002. Poststructuralism: A Very Short Introduction. Oxford and New York: Oxford University Press.

Blake, W. 1994. The Marriage of Heaven and Hell. New York: Dover.

Bristow, J. Sexuality. 1997. London and New York: Routledge.

Bukatman, S. 1993. Terminal Identity: The Virtual Subject in Postmodern Science Fiction. Durham, NC, and London: Duke University Press.

CAmus, A. 1991. The Myth of Sisyphus. New York: Vintage International.

Cioran, E. M. 1970. The Fall into Time. Chicago: Quadrangle.

Clarke, D. B. 2003. The Consumer Society and the Postmodern City. London and New York: Routledge.

Delville, M. 1988. J.G. Ballard. Plymouth: Northcote House.

DePPER, C. 2008. "Death at Work: The Cinematic Imagination of J.G. Ballard". J.G. Ballard. Ed. J. Baxter. London and New York: Continuum. 50-65.

DerY, M. 2006. “'Always Crashing in the Same Car': A Head-on Collision with the Technosphere", The Sociological Review 54,1: 223-39.

Derr, M. 2014. “J.G. Ballard's Wild Ride". Extreme Metaphors: Selected Interviews with J.G. Ballard, 1967-2008. Eds. S. Sellars and D. O’Hara. London: Fourth Estate. 339-48.

Dienstag, J. F. 2006. Pessimism: Philosophy, Ethic, Spirit. Princeton, NJ, and Oxford: Princeton University Press.

Du ToIt, A. 2011. “Grand Narrative, Metanarrative”. The Lyotard Dictionary. Ed. S. Sim. Edinburgh: Edinburgh University Press. 86-88.

Eagleton, T. 1997. "Self-Undoing Subjects". Rewriting the Self: Histories from the Renaissance to the Present. Ed. R. Porter. London and New York: Routledge. 262-69.

Eagleton, T. 2007. The Meaning of Life: A Very Short Introduction. Oxford and New York: Oxford University Press.

Featherstone, M. 2007. Consumer Culture and Postmodernism. Los Angeles and London: Sage.

Felluga, D. F. 2015. Critical Theory: The Key Concepts. London and New York: Routledge.

Freud, S. 2001. Totem and Taboo: Some Points of Agreement between the Mental Lives of Savages and Neurotics. London and New York: Routledge. 
Freud, S. 2003. Beyond the Pleasure Principle and Other Writings. London and New York: Penguin.

GasioneK, A. 2005. J. G. Ballard. Manchester and New York: Manchester University Press.

GraY, J. 2014. "'Technology is Always a Facilitator': J.G. Ballard on Super-Cannes". Extreme Metaphors: Selected Interviews with J.G. Ballard, 1967-2008. Eds. S. Sellars and D. O'Hara. London: Fourth Estate. 374-82.

Harpold, T. 1997. “Dry Leatherette: Cronenberg's Crash”. Postmodern Culture 7, 3: n. p. 4 April 2016. http://search.proquest.com.ezproxy.uned.es/ docview/1426661315?OpenUrlRefId=info:xri/sid:summon\&accountid=14609.

Heidegger, M. 2000. Introduction to Metaphysics. New Haven, CT, and London: Yale University Press.

Homer, S. 2005. Jacques Lacan. London and New York: Routledge.

HuntLey, J. 2008. 'Disquieting Features: An Introductory Tour of The Atrocity Exhibition'. J.G. Ballard. Ed. J. Baxter. London and New York: Continuum. 23-33.

IngLIS, D. 2005. "Auto Couture: Thinking the Car in Post-War France”. Automobilities. Eds. M. Featherstone, N. Thrift, and J. Urry. London and Thousand Oaks, CA: Sage. 197-219.

Iocco, M. 2007. "Addicted to Affliction: Masculinity and Perversity in Crash and Fight Club". Gothic Studies 9, 2: 46-56.

Jenks, C. 2003. Transgression. London and New York: Routledge

KeAY, D. "No such Thing as Society”. Woman's Own. 22 September 1987. http://www. margaretthatcher.org/document/106689.

Kristeva, J. 1982. Powers of Horror: An Essay on Abjection. New York: Columbia University Press.

LAnger, L. L. 2003. “The Dominion of Death". Elie Wiesel's Night. Ed. H. Bloom. New York: Chelsea House. 3-16.

Lipovetsky, G. 2000. El crepúsculo del deber: La ética indolora de los nuevos tiempos democráticos. Barcelona: Anagrama.

LiTt, T. 2014. “'Dangerous Bends Ahead. Slow Down': J.G. Ballard on Kingdom Come" Extreme Metaphors: Selected Interviews with J.G. Ballard, 1967-2008. Eds. S. Sellars and D. O'Hara. London: Fourth Estate. 415-30.

Lyotard, J-F. 1984. The Postmodern Condition: A Report on Knowledge. Minneapolis: University of Minnesota.

MacGregor, C. 2006. "The Eye of the Storm - Female Representation in Bataille's Madame Edwarda and Histoire de l'oeil'. The Beast at Heaven's Gate: Georges Bataille and the Art of Transgression. Ed. A. Hussey. Amsterdam and New York: Rodopi. 101-10.

MCAFEe, N. 2004. Julia Kristeva. London and New York: Routledge. 
Naughtie, J. 2014. "Up a Kind of Sociological Amazon. J.G. Ballard on Miracles of Life". Extreme Metaphors: Selected Interviews with J.G. Ballard, 1967-2008. Eds. S. Sellars and D. O'Hara. London: Fourth Estate. 473-83

Nietzsche, F. 1968. The Will to Power. New York: Vintage.

Noys, B. 2005. The Culture of Death. Oxford and New York: Berg.

Paglia, C. 2001. Sexual Personae: Art and Decadence from Nefertiti to Emily Dickinson. London and New Haven, CT: Yale University Press.

READER, K. 2006. The Abject Object: Avatars of the Phallus in Contemporary French Theory. Amsterdam and New York: Rodopi.

Rønnov-Jessen, P. 2014. “Against Entropy”. Extreme Metaphors: Selected Interviews with J.G. Ballard, 1967-2008. Eds. S. Sellars and D. O’Hara. London: Fourth Estate. 199-210.

Sage, V. 2008. "The Gothic, the Body, and the Failed Homeopathy Argument: Reading Crash”. J.G. Ballard. Ed. J. Baxter. London and New York: Continuum. 34-49.

SELF, W. 2014. "Conversations: J.G. Ballard”. Extreme Metaphors: Selected Interviews with J.G. Ballard, 1967-2008. Eds. S. Sellars and D. O’Hara. London: Fourth Estate. 299-319.

Silverman, M. 1999. Facing Postmodernity: Contemporary French Thought on Culture and Society. London and New York. Routledge.

StePhenson, G. 1991. Out of the Night and into the Dream: A Thematic Study of the Fiction of J. G. Ballard. New York: Greenwood Press.

Stoekl, A. 1985. Politics, Writing, Mutilation: The Cases of Bataille, Blanchot, Roussel, Leiris, and Ponge. Minneapolis: University of Minnesota.

STORR, A. 2001. Freud: A Very Short Introduction, Oxford and New York: Oxford University Press.

TANner, M. 2000. Nietzsche: A Very Short Introduction. Oxford and New York: OUP.

Thomas, M. 2011. "The Rules of Autogeddon: Sex, Death and Law in JG Ballard's Crash". Griffith Law Review 20, 2: 333-62.

Thurschwell, P. 2000. Sigmund Freud. London and New York: Routledge.

Vale, V. 2014. "Interview with JGB”. Extreme Metaphors: Selected Interviews with J.G. Ballard, 1967-2008. Eds. S. Sellars and D. O’Hara. London: Fourth Estate. 146-69.

Vatтimo, G. 1987. El fin de la modernidad: nihilismo y hermenéutica en la cultura posmoderna. Barcelona: Gedisa.

WeIss, J. 2014. "'Not Entirely a Journey without Maps': J.G. Ballard on The Atrocity Exhibition". Extreme Metaphors: Selected Interviews with J.G. Ballard, 1967-2008. Eds. S. Sellars and D. O'Hara. London: Fourth Estate. 447-62.

Wicks, R. 2003. Modern French Philosophy: From Existentialism to Postmodernism. Oxford: Oneworld.

Woodward, A. 2009. Nihilism in Postmodernity. Aurora, CO: The Davies Group.

ZINIK, Z. 2014. "Russia on my Mind”. Extreme Metaphors: Selected Interviews with J.G. Ballard, 1967-2008. Eds. S. Sellars and D. O’Hara. London: Fourth Estate. 356-63. 